\title{
Studies on Dextran-degrading Enzymes. Isolation and Identification of a Dextranase-producing Strain of Cytophaga johnsonii and Studies on the Formation of the Surface-bound Enzyme
}

\author{
By J.-C. J A NSON \\ Institute of Biochemistry, University of Uppsala, 75 I 2 I Uppsala I, Sweden
}

(Received I 2 September 1973; revised 25 November 1974)

\section{SUM MAR Y}

A dextranase-producing, aerobic Gram-negative bacterium closely related to Cytophaga johnsonii has been isolated. The dextranase is attached to the outer membrane of the envelope. Dextran is required as an inducer in the culture medium; when grown on starch or gelatin, membrane-bound amylase and proteinase are synthesized adaptively.

\section{INTRODUCTION}

The synthesis of dextranases [ $\alpha$-D-(I,6)-glucan 6-glucanohydrolase; EC. 3.2.I.II] has been noted in a variety of micro-organisms, including some bacteria (Ingelman, I948; Hehre \& Sery, 1952; Clarke, 1959; Janson \& Porath, 1966; Zevenhuizen, I968; Richards \& Streamer, 1972). The present investigation deals with the isolation of a dextranaseproducing strain of Cytophaga johnsonii, and studies on the formation of the membranebound enzyme.

\section{METHODS}

Isolation of the organism. The bacterium was isolated from a gel filtration column (Sephadex G-100, Pharmacia), which had partially decomposed, accidentally, after a few months' storage in neutral phosphate buffer at room temperature in the absence of any preserving agent. Samples were withdrawn from the bottom part of the column and used as inocula for the dextran enrichment medium, which had the following composition (per litre distilled water): $\mathrm{KH}_{2} \mathrm{PO}_{4}(\mathrm{I} 3.6 \mathrm{~g}),\left(\mathrm{NH}_{4}\right)_{2} \mathrm{SO}_{4}(2 \cdot 0 \mathrm{~g}), \mathrm{MgSO}_{4} \cdot 7 \mathrm{H}_{2} \mathrm{O}(0 \cdot 2 \mathrm{~g}), \mathrm{FeSO}_{4}$. ${ }_{7} \mathrm{H}_{2} \mathrm{O}(0.5 \mathrm{mg})$; the $\mathrm{pH}$ of the medium was adjusted to $7^{\circ} 0$ with $\mathrm{KOH}$, and dextran (mol. wt $40000)$ was added to a concentration of $\mathrm{I} \%(\mathrm{w} / \mathrm{v})$. Conical flasks containing $25 \mathrm{ml}$ medium were shaken at $30{ }^{\circ} \mathrm{C}$. After about a week a silky, yellow growth could just be observed in one of the flasks. Inocula from the culture were spread on dextran agar (same medium as in the flasks plus $\mathrm{I} \cdot 5 \% \mathrm{w} / \mathrm{v}$, Difco Bacto agar). Yellow colonies developed within two days, and several transfers were performed with isolated colonies before the culture was considered pure. The culture was preserved as lyophilized ampoules stored at $-35{ }^{\circ} \mathrm{C}$.

The strain has been deposited in the culture collection of the Northern Regional Research Laboratory (U.S. Department of Agriculture), Peoria, Illinois, U.S.A., reference number NRRL B4 I 80.

Growth conditions. The growth experiments were performed in conical flasks (Erlenmeyer or Fernbach) incubated at $30{ }^{\circ} \mathrm{C}$ on rotatory shakers. The volume of the medium was adjusted to a depth of a few millimetres to ensure proper aeration. The mineral salts medium described above was used, and the sources of carbon and other compounds were added as

Vol. 88, No. I was issued May 1975 
sterile solutions. Growth was followed quantitatively by measuring the turbidity of culture samples in a spectrophotometer at $540 \mathrm{~nm}$. The dextran used as substrate in most experiments was Dextran Ti 50 (Pharmacia).

Enzyme assay. Dextranase activity was assayed essentially as described by Janson \& Porath (I966) except that incubation took place at $40{ }^{\circ} \mathrm{C}$. We used $200 \mu \mathrm{l}$ Cytophaga suspension of culture supernatant as samples. After the addition of the 3,5 -dinitrosalicylic acid reagent and heating, the reagent mixtures and the appropriate blanks containing bacteria were centrifuged. One dextranase unit is defined as the amount of enzyme necessary to liberate reducing groups corresponding to the formation of $\mathrm{I} \mu \mathrm{mol}$ isomaltose/minute at $40{ }^{\circ} \mathrm{C}$.

\section{RESULTS}

\section{Characteristics of the dextranase producing strain of Cytophaga johnsonii}

Morphological. Narrow, long $(0.5 \times 5$ to $8 \mu \mathrm{m})$, often irregularily bent, flexible rods with rounded ends. Old rods coccoid in shape. Gliding movement.

Cultural. On peptone, dextran, starch, cellodextrin, sucrose and glucose agar the colonies were weakly convex, smooth, yellow, transparent and with a smooth edge; they were I to $2 \mathrm{~mm}$ in diameter. Occasionally, whole plates or parts thereof swarmed. At low nutrient concentrations, the colonies were always surrounded by swarming bacteria. In liquid media the cultures were yellow to orange-yellow, and silky in appearance because of the long rods. In old ( $>15 \mathrm{~h}$ ) dextran or starch cultures a typical yeast-like aroma occurred.

Physiological. Strictly aerobic, nitrites produced from nitrates, catalase produced, indole negative, optimum temperature 25 to $30^{\circ} \mathrm{C}$, maximum temperature $3 \mathrm{I}^{\circ} \mathrm{C}$.

\section{Identification of the bacteria isolated}

The morphological characteristics, type of movement, low refractibility and absence of microcysts of the strain are typical of the non-microcyst-forming primitive myxobacteria, i.e. the Cytophaga group, and its characteristics fit most closely with those of $C$. johnsonii (Stanier, 1947); this identification has been confirmed by Dr D. M. Webley at the Macaulay Institute for Soil Research, Craigebuckler, Aberdeen. The type strain of $C$. johnsonii has been characterized as strongly chitinolytic, but our isolate showed very weak chitinolytic activity. Both strains are capable of utilizing a variety of carbohydrates, which reflects their ability to synthesize glycanases as well as $\alpha$ - and $\beta$-glycosidases.

\section{Studies on the formation of the dextranase}

Bound enzyme. Cytophaga johnsonii strain Uppsala grew rapidly with high molecular weight dextran as the sole source of carbon and energy. The generation time during the exponential phase was approximately $120 \mathrm{~min}$. No dextranase activity could be detected in the cell-free culture medium. Instead, this was bound to the bacteria and could readily be assayed under conditions where the organism was incapable of growth: $40{ }^{\circ} \mathrm{C}$ and in the presence of $0.01 \%$ merthiolate or $0.02 \%$ sodium azide. Figure I shows the result of a growth experiment where dextranase was assayed both in the superantant and in the resuspended bacteria. As an indicator of lysis the cytoplasmic $\alpha$-glucosidase (isomaltase) activity was used. This experiment clearly demonstrated the cell-bound character of the dextranase of $C$. johnsonii. Similar experiments on enzymes of Cytophaga species have not been reported but other evidence indicated the cell-bound character of the cellulase of Cytophaga sp. (Stanier, 1942; Fåhraeus, 1947) and the chitinase of $C$. johnsonii (Stanier, I947). In our isolate we have also demonstrated the cell-bound character of adaptively synthesized amylase and proteinase. 


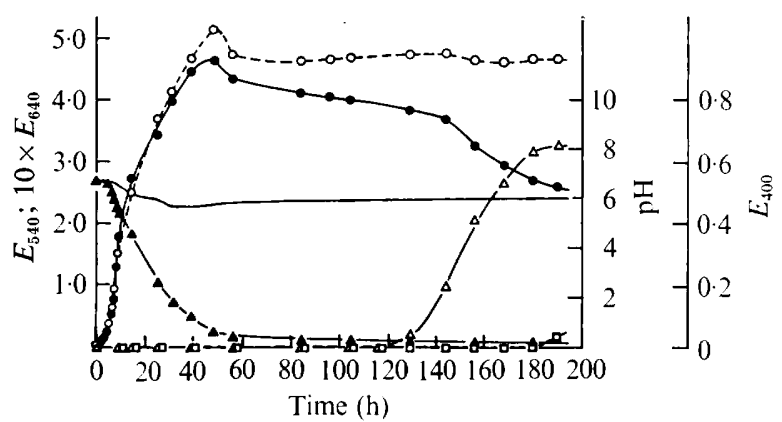

Fig. I

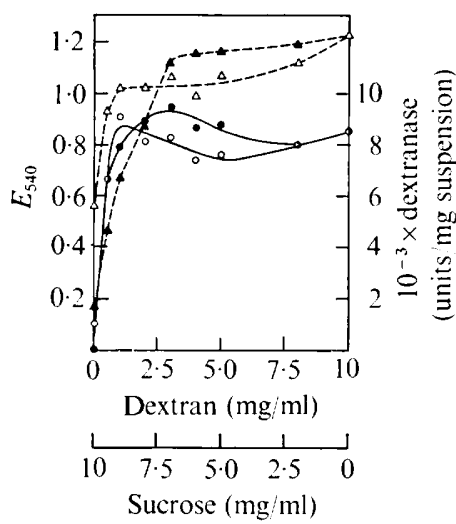

Fig. 2

Fig. I. Growth and dextranase formation on I \% Dextran T I 50. Growth was followed by measuring $E_{540}$ on diluted samples. Dextranase activity was measured on washed and resuspended bacteria. Samples $(50 \mathrm{ml})$ were withdrawn at intervals from the initial $1500 \mathrm{ml}$ of culture medium in a $30 \mathrm{~cm}$ diam Fernbach flask. After centrifugation, the bacteria were washed once with $10 \mathrm{ml}$ of $0.1 \mathrm{M}$ potassium phosphate buffer $\mathrm{pH} 6.0$ and resuspended in $1 \mathrm{ml}$ of the same buffer. Samples $(200 \mu \mathrm{l})$ were used in the dextranase assay. Samples ( $10 \mathrm{ml}$ ) of the supernatants were concentrated to $\mathrm{I} \mathrm{ml}$ in collodium sacs, dialysed against the phosphate buffer and used for the assay of dextranase ( $200 \mu \mathrm{l}$; $30 \mathrm{~min})$ and $\alpha$-glucosidase $(100 \mu \mathrm{l} ; 30 \mathrm{~min})$. Decrease in the substrate concentration was followed using the orcinol-sulphuric acid reagent. $O$, Dextranase activity in bacteria $\left(E_{640}\right)$; $\left(E_{540}\right) ;--, \mathrm{pH} ; \boldsymbol{\Lambda}$, substrate (dextran) concentration; $\triangle, \alpha$-glucosidase activity in supernatant; $\square$, dextranase activity in supernatant.

Fig. 2. Dextranase formation as a function of Dextran T I 50 concentration in the culture medium. Experimental conditions as for Fig. I. Incubation time $18 \mathrm{~h} . \Delta, \boldsymbol{\Delta}$, cell density $\left(E_{\varepsilon 40}\right) . \bigcirc, \boldsymbol{O}$, dextranase activity, $\angle, C$, medium containing dextran and sucrose; $\boldsymbol{\Delta}, \boldsymbol{O}$, medium containing dextran.

Effect of $p H$. The effect of the starting $\mathrm{pH}$ of the culture medium on the growth rate with high molecular weight dextran as the sole source of carbon and energy was tested. The highest growth rates and best conditions for dextranase synthesis were obtained at $\mathrm{pH} 6.0$ to $7 \cdot 0$, whereas slower growth was obtained at $\mathrm{pH} 5.5$ and $9 \cdot 0$ and very slow at $5 \cdot 0$.

Effect of dextran concentration. The formation of dextranase was studied as a function of the dextran concentration in the medium (i) with dextran as the sole source of carbon and (ii) with a constant supply of carbon and energy, through the addition of increasing amounts of sucrose (Fig. 2). The amount of dextranase formed was highly correlated with the extinction (Fig. 1). When the dextran concentration exceeded approximately $2 \mathrm{mg} / \mathrm{ml}$, more bacteria and consequently larger amounts of dextranase were obtained during growth on dextran alone than as a dextran-sucrose mixture (Fig. 2). At lower dextran concentrations the cell density was higher in the presence of sucrose and thus the amount of dextranase was higher than in the absence of the disaccharide. However, the quantity of dextranase did not exceed that obtained with dextran alone at higher concentrations. The synthesis of dextranase was apparently dextran-dependent and sucrose neither induced nor repressed its formation.

Effect of detergent concentration. The effect of the addition of detergent to the culture medium was tested. The conditions were as in the other growth experiments except that the growth medium also contained increasing concentration of the non-ionic detergent Triton $\mathrm{X}$-IOO (octylphenoxypolyethoxyethanol). At detergent concentrations of up to $0.0 \mathrm{I} \%$ the bacteria grew as fast as the control culture but the final cell density was reduced to approximately $80 \%$. At $0.0 \mathrm{I} \%$ Triton X-100 about $90 \%$ of the dextranase was found in the cell-free culture supernatant as was most of the coloured material. 


\section{DISCUSSION}

There are four possible locations for cell-bound enzymes of Gram-negative bacteria: (i) in the outer membrane, (ii) in the periplasmic space, (iii) in the cytoplasmic membrane and (iv) in the cytoplasm. Enzymes located in (ii) or (iv) are released when the bacteria are disintegrated and are obtained in the supernatant after centrifugation. The dextranase of Cytophaga johnsonii Uppsala was found in the sediment and thus it cannot be regarded as either a cytoplasmic or a periplasmic enzyme. Of the remaining possible locations, (i) and (iii), the former is the more likely, because the organism can utilize insoluble (cross-linked) dextran (Sephadex G-50-G-200) as the sole source of carbon and energy and complete solubilization of such particles may easily be demonstrated with suspensions of whole organisms under non-growth conditions. One finds the bacteria in close contact with and even penetrating the dextran gel particles, an observation consistent with the findings of Fåhraeus (I947) concerning the behaviour of the cellulose-decomposing Cytophaga species.

Pollock (I962) suggests three tests for proving an enzyme to be on the surface. One concerns the metabolism of strictly insoluble, highly polymerized substrates; the others concern specific extraction and specific inhibition procedures with substances unlikely to penetrate the permeability barrier, such as enzymes or antibodies respectively. Preliminary analysis by electron microscopy with sectioned bacteria treated with Triton X-100, which completely solubilizes the dextranase activity, shows that the outer membrane is fractured but that the rest of the envelope is left intact (J.-C. Janson and A. von Hofsten, unpublished results). The growth experiments performed in the presence of low concentrations of Triton $\mathrm{X}$-I0o provide further evidence that the dextranase is located in the outer membrane of the envelope of this bacterium. Observations in the light microscope showed that shape was unaffected by the detergent present in the growth medium. However, as no electronmicroscopic analysis was made on thin sections there is no direct information about the effect of this treatment on the membrane.

The invaluable support of Professor Jerker Porath and skilful technical assistance of Mrs Marie Sundqvist are gratefully acknowledged.

\section{REFERENCES}

Clarke, R. T. J. (1959). A dextran-fermenting organism from the rumen closely resembling Lactobacillus bifidus. Journal of General Microbiology 20, 549-553.

FÅHraeus, G. (1947). Studies in the cellulose decomposition by Cytophaga. Symbolae botanicae upsaliensis 9 $2, I-128$.

Hehre, E. J. \& Sery, T. W. (I952). Dextran-splitting anaerobic bacteria from the human intestine. Journal of Bacteriology $63,424-426$.

Ingelman, B. (1948). Enzymatic breakdown of dextran. Acta chemica scandinavica 2, 803-812.

JAnson, J.-C. \& Porath, J. (1966). A bacterial dextranase. In Methods in Enzymology, vol. 8, pp. 615-621. Edited by E. F. Neufeld and V. Ginsburg. New York: Academic Press.

Pollock, M. R. (1962). Exoenzymes. In The Bacteria, vol. 4, pp. 121-178. Edited by I. C. Gunsalus and R. Y. Stainer. New York: Academic Press.

Richards, G. N. \& Streamer, M. (1972). Studies on dextranases. I. Isolation of extracellular, bacterial dextranases. Carbohydrate Research 25, 323-332.

STANIER, R. Y. (I942). The Cytophaga-group: a contribution to the biology of Myxobacteria. Bacteriological Reviews 6, 143-196.

Stanier, R. Y. (1947). Studies on non-fruiting myxobacteria. I. Cytophaga johnsonae, n. sp., a chitindecomposing myxobacterium. Journal of Bacteriology 53, 297-31 5.

Zevenhuizen, L. P. T. M. (1968). Cell-bound exo-dextranase of Bacillus species. Carbohydrate Research 6, $310-318$. 